\title{
THE DYNAMIGS OF AVALANCHING IN THE KHIBINS
}

\author{
By V. M. Kotlyakov, B. N. Rzhevskiy and V. A. Samoylov \\ (Institut Geografii, Akademiya Nauk SSSR, Staromonetny 29, Moskva 109o17, U.S.S.R.)
}

\begin{abstract}
Results of ten-year measurements of avalanche impact upon a large-sized installation are shown. The installation is equipped with 20 pressure sensors using the principle of the intrusion of a steel cone into a duralumin plate. The impacts of 30 dry avalanches with volumes from too up to 50 coo $\mathrm{m}^{3}$ are analysed. A maximum pressure at "a point" of I $100 \mathrm{kN} / \mathrm{m}^{2}$ and a pressure of $650 \mathrm{kN} / \mathrm{m}^{3}$ averaged over the area of the installation $\left(24 \mathrm{~m}^{2}\right)$ were recorded. It is found that $75^{\circ}$ of the impact energy is concentrated in the lowest $2 \mathrm{~m}$ of the installation. Proceeding from these data, and also taking into account that the thickness of an avalanche body amounts to $10-20 \mathrm{~m}$ at the moment of impact, we may conclude, that there is a "dense core" and an upper "high aerosol" part in an avalanche body.

The use of stereo-photogrammetric surveys of moving avalanches revealed the "velocity depression" effect in the Khibin avalanches: Avalanche velocity decreases abruptly (by a factor 1.5 to 2 ) at the end of transit channel and then grows rapidly up to a maximum at the end of the avalanche cone. The greatest variations of velocity amount to $51 \mathrm{~m} / \mathrm{s}$.

The data obtained prove the inefficiency of anti-avalanche filling dams, especially because of their negative role in the generation of disasterous air waves, whose pressure varies from 20 up to $150 \mathrm{kN} / \mathrm{m}^{2}$.

RÉsumé. Dynamique des avalanches dans les Khibins. On montre les résultats de dix ans de mesures d'impacts d'avalanches sur un obstacle de grande dimension. L'installation est équipée de 20 capteurs de pression utilisant le principe de la pénétration d'un cone d'acier dans une plaque d'alliage d'aluminium. On a analysé les impacts de 30 avalanches de neige sèche avec des volumes de 100 à $50000 \mathrm{~m}^{3}$. On a enregistré des maxima de $1100 \mathrm{kN} / \mathrm{m}$ * pour la pression "en un point" et de $650 \mathrm{kN} / \mathrm{m}$ " pour la pression moyenne sur les $24 \mathrm{~m}^{2}$ de l'installation. On a montré que $75 \%$ de l'énergie d'impact est concentrée dans la partie inférieure de l'installation sur deux mètres de haut. A partir de ces données. et, compte tenu également que l'épaisseur du corps de l'avalanche au moment de l'impact va jusqu'à ro ou $20 \mathrm{~m}$, on peut conclure qu'il y a dans l'avalanche un "noyau dense" et une partie supérieure en "aérosol haut".

L'utilisation d'observations stéréo-photogrammétriques du mouvement de l'avalanche a permis de mettre en évidence une "chute de vitesse" dans les avalanches des Khibins. La vitesse de l'avalanche tombe brusquement $(1,5$ à 2 fois) à la fin du couloir de transit, puis augmente rapidement jusqu'au maximum à l'extrémité du cone d'avalanche. Les plus grandes variations de vitesse atteignent $51 \mathrm{~m} / \mathrm{s}$.

Les résultats obtenus prouvent l'inefficacité des barrages anti-avalanches pleins, spécialement à cause de leur rôle négatif dans la génération d'ondes désastreuses dans l'air dont la pression totale varie de 20 à 150
\end{abstract} $\mathrm{kN} / \mathrm{m}^{2}$.

Zusammenfassung. Dynamik von Lawinen in den Khibin-Bergen. Die Ergebnisse zehnjähriger Messungen des. Aufpralles von Lawinen auf eine grossformatige Verbauung werden mitgeteilt. Die Verbauung ist mit 20 Drucksensoren versehen, die auf dem Prinzip des Eindringens eines Stahlkegels in eine Platte aus Duraluminium beruhen. Der Aufprall von 30 trockenen Lawinen mit Volumina von 100 bis $\mathrm{zu}_{50} 000 \mathrm{~m}^{3}$ wierd analysiert. Die Aufzeichnungen crgaben einen "punktuellen" Maximaldruck von 1 10o $\mathrm{kN} / \mathrm{m}=\mathrm{und}$ einen mittleren Druck von $650 \mathrm{kN} / \mathrm{m}$ : auf die Verbauungsfläche von $24 \mathrm{~m}=$. Es lässt sich feststellen. dass $75^{\circ}$ der Aufprallenergie auf den unteren, $2 \mathrm{~m}$ hohen Teil der Verbauung konzentriert ist. Ausgehend von diesen Daten und unter Berücksichtigung der Tatsache. dass die Dicke eines Lawinenkörpers beim Aufprall ro-20 $\mathrm{m}$ beträgt, lässt sich schliessen, dass ein Lawinenkörper in einen "dichten Kern" und ein "oberes Aerosol" darüber unterteilt ist.

Aus stereophotogrammetrischen Aufnahmen abgehender Lawinen konnte der Effekt der "Geschwindigkeitsabnahme" bei den Khibin-Lawinen entdeckt werden. Die Lawinengeschwindigkeit sinkt plötzlich $\left(1,5^{-2}\right.$ fach $)$ am Ende des Bahnkanals und wächst dann wieder schnell bis zu ihrem Maximum am Ende des Lawinenkegels. Die grössten Geschwindigkeitsschwankungen erreichen $51 \mathrm{~m} / \mathrm{s}$.

Die gewonnenen Daten erweisen die Unwirksamkeit von Fülldämmen zur Lawinenabwehr, vor allem infolge ihrer schadlichen Rolle bei der Frzeugung verheerender Luftwellen, deren Druck von 20 bis zu $150 \mathrm{kN} / \mathrm{m}$ : reicht.

The first studies of the dynamics of avalanching in the Khibins were fulfilled in $1937-39$ (Goff and Otten, 1939). A new cycle of studies was connected with the construction of a large-scale installation for the measurements of avalanche impact in 1966 .

The installation is located on the avalanche cone called the "Apatite Crater" at a distance of $700 \mathrm{~m}$ from the avalanche source. A steel framework, designed to stand a pressure of $400 \mathrm{kN} / \mathrm{m}^{2}$, is mounted on a ferro-concrete foundation. The plane repelling the impact has a height of $8.5 \mathrm{~m}$ including the foundation (Fig. I). It is equipped with 20 sensors based on the principle of intruding a steel cone into a duralumin plate whose dynamic hardness practically coincides with its static hardness (Vitman and Yoffe, 1948). Besides, experiments showed that 
the time of the growth of load during the avalanche impact is much longer than the period of natural oscillations of the installation (about $50 \mathrm{~Hz}$ ), which allows us to apply a statistical method of calibrating the sensors (Goff and Otten, 1941; Isayenko, 1972).
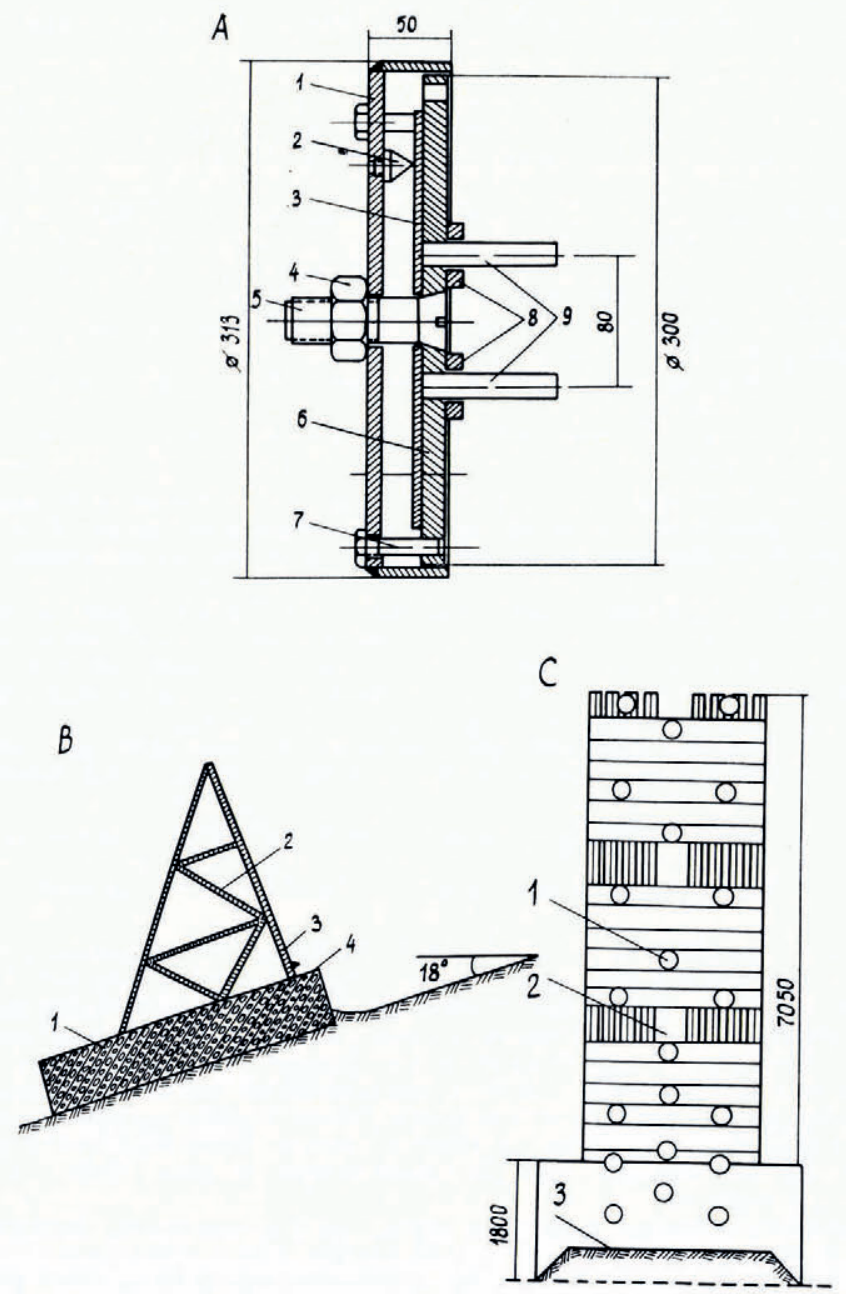

Fig. $I$. Installation for the measurements of avalanche impact.

A. Arrangement of the sensor: 1 -movable disk; 2-cone; 3-duralumin plate; 4-central nut; 5-central bolt; 6 -fixed disk; 7-stop pin; 8-washers; 9- lock pins.

B. Longitudinal section of the installation: I-foundation; 2-metal framework; 3-the zone of "impact shadow"; 4-the shelf of the foundation.

C. Working facet of the installation: 1-sensor; 2-opening; 3-level of the underlying surface.

The above-mentioned method of determining the equivalent loadings of an avalanche impact has been repeatedly used by earlier researchers (Spindler, I957; Shōda, I966; Shimizu and others, 1974). The methods used in the Khibins experiment are the subject of a special paper (Rzhevskiy and Nechayev, 1975).

The velocity of the avalanche front is determined by means of terrestrial stereophotogrammetry. The equipment consists of two aerial cameras, working synchronously and automatically at the time interval of (2.00 \pm 0.02$) s$ (Samoylov and Bryukhanov, 1975). 
The time at which the avalanche passes marked parts of the route is also determined with the help of filming and electrical pulse gauges.

Measurements of the specific weight of snow before $\left(\gamma_{1}\right)$ and after $\left(\gamma_{2}\right)$ the impact are made by a rotary density gauge, equipped with a cutter, which simplifies the selection of samples of packed snow. $\gamma_{\mathrm{I}}$ is the specific weight of blocks of avalanche snow which, as a rule, form avalanches in the Khibins. Linear dimensions typical of such blocks vary from o. I to $0.5 \mathrm{~m}$. Measurements of $\gamma_{2}$ embrace the snow layer adjacent to the impact plane, and also snow layers situated close to it. According to the data from 600 measurements, $\gamma_{1}$ varies from I. 5 to $4.0 \mathrm{kN} / \mathrm{m}^{3}$, and $\gamma_{2}$ from 2.0 up to $6.0 \mathrm{kN} / \mathrm{m}^{3}$.

The interaction of 30 dry avalanches, their volume varying from roo to $50000 \mathrm{~m}^{3}$, with the installation was studied during the years $1967-76$. Spontaneous avalanches as well as avalanches triggered by mine fire were among them. Of all the vast amount of information obtained experimentally, only the most important data, from the applied point of view, have so far been analysed.
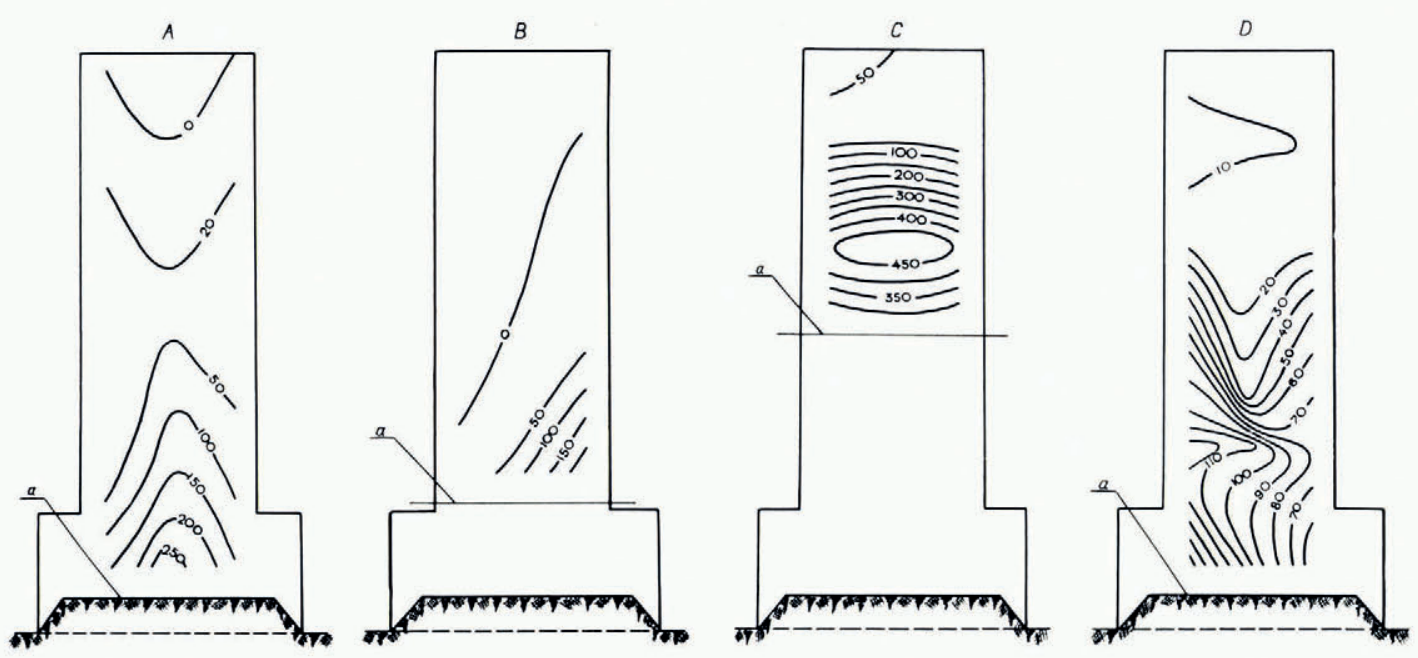

Fig. 2. Examples of the pressure distribution over the surface of the installation $\left(\right.$ in $\left.\mathrm{kN} / \mathrm{m}^{2}\right)$; a-the level of the underlying surface (in $A, D$-the soil, in $B, C$-deposits of previous avalanches).

The relatively low accuracy of some parameters obtained in field conditions, and also a number of necessary assumptions and limitations, forced the authors to use mainly the maximum characteristics of snow and ice in their analysis. However, this may be considered quite tolerable for the applied aspect.

It has been established primarily, that the absolute values of avalanche pressure in the Khibins reach $45^{0}-650 \mathrm{kN} / \mathrm{m}^{2}$ averaged over the area of impact (up to $24 \mathrm{~m}^{2}$ ) and I roo $\mathrm{kN} / \mathrm{m}^{2}$ for the "point" of impact, registered by one of the sensors. The great destructive force of Khibin avalanches was, thus, confirmed numerically.

At the moment of impact avalanche parameters (velocity, specific weight, etc.) vary greatly, which is reflected in the nature of the pressure distribution about the plane of collision (Fig. 2). Despite all the diversity of these "dynamic portraits" of avalanches, common features can be traced in all of them, first of all a regular decrease of pressure as height increases. This is graphically shown in Figure $3 \mathrm{~A}$, where the curve is drawn through the points characterizing the pressure averaged for altitudinal intervals. 

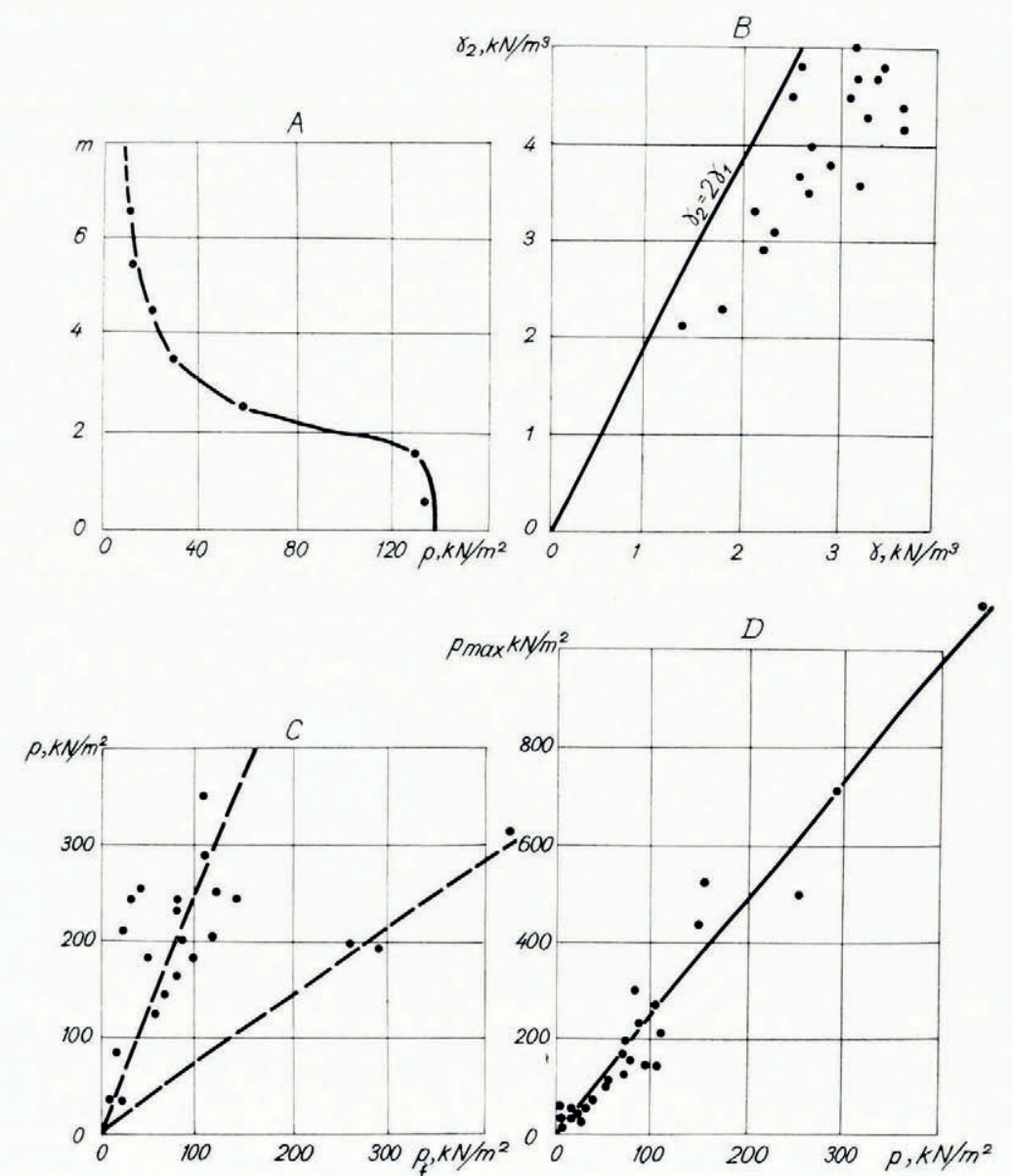

Fig. 3. A. Distribution of pressure with height on the installation according to mean data; $B$. The nature of the relationship between the specific weight of the avalanche before $\left(\gamma_{1}\right)$ and after the impact $\left(\gamma_{2}\right) ; C$. Relationship between the mean measured $\left(p_{\mathrm{f}}\right)$ and calculated $(p)$ pressures; D. Relationship between the mean and maximum pressures.

Numerous measurements of $\gamma_{1}$ and $\gamma_{2}$ allow us to determine the nature of the relationship between them, necessary for the application of some theoretical formulae (Fig. $3^{\mathrm{B}}$ ). If the maximum values of $\gamma_{2}$ are used, this relation will be: $\gamma_{2}=2 \gamma_{1}$, which coincides with existing theoretical estimates (Dolov and Khalkechev, I972). We think it advisable to use the equation obtained together with a theoretical formula for the calculation of avalanche loadings:

$$
p=\frac{\gamma_{1} \gamma_{2} v^{2}}{g\left(\gamma_{2}-\gamma_{1}\right)} .
$$

This equation, obtained on the basis of the most universal common basic laws of mechanics, the laws of mass and momentum conservation, is known as the formula of S. Khristyanovich (Sredneasiatskiy Nauchno-Issledovatel'skiy Gidrometeorologicheskiy Institut, I965).

Replacing $\gamma_{2}$ in (I) by $2 \gamma_{1}$ we can transform it into a semi-empirical equation:

$$
p=2 \gamma_{\mathrm{I}} v^{2} / g
$$

which is recommended for calculating the mean avalanche pressure upon a barrier. 
Comparison of the actual avalanche pressures with those calculated according to $p=\gamma_{\mathrm{I}} v^{2} / g$ (Fig. 3c), established two separate groups of points. In one of the groups, comprising the majority of avalanches, we have the best agreement when $p=\gamma_{1} v^{2} / 2 g$, which is identical with relocity (dynamic) pressure.

For the remaining three points, corresponding to avalanches with the smallest $\gamma_{1}$, the greatest compacting coefficients $\gamma_{2} / \gamma_{\mathrm{I}}=\mathrm{I} .8-\mathrm{I} .9$, and with the maximum values of pressure, the best agreement is reached, when $p=1.5 \gamma_{1} v^{2} / g$. Consequently, the semi-empirical Equation (2) provides adequate results for the calculation of loadings of Khibin avalanches with extreme parameters.

In the case of an anti-avalanche construction longer than the experimental installation, the avalanche pressure averaged over the area is sure to be less, due to its decrease at the edges, but the quantitative magnitude of this assumption has not yet been found. It is noteworthy that on two occasions the plane of collision was artificially enlarged by creating a wall from previous avalanche deposits, which prevented the avalanches from flowing round the installation. The values of pressure obtained did not differ from the remaining data.

There exists a close relationship between the mean avalanche pressure $p$ on the experimental installation and the maximum value $p_{\max }$ recorded by any one sensor (Fig. 3D):

$$
p_{\max }=2.4 p \text {. }
$$

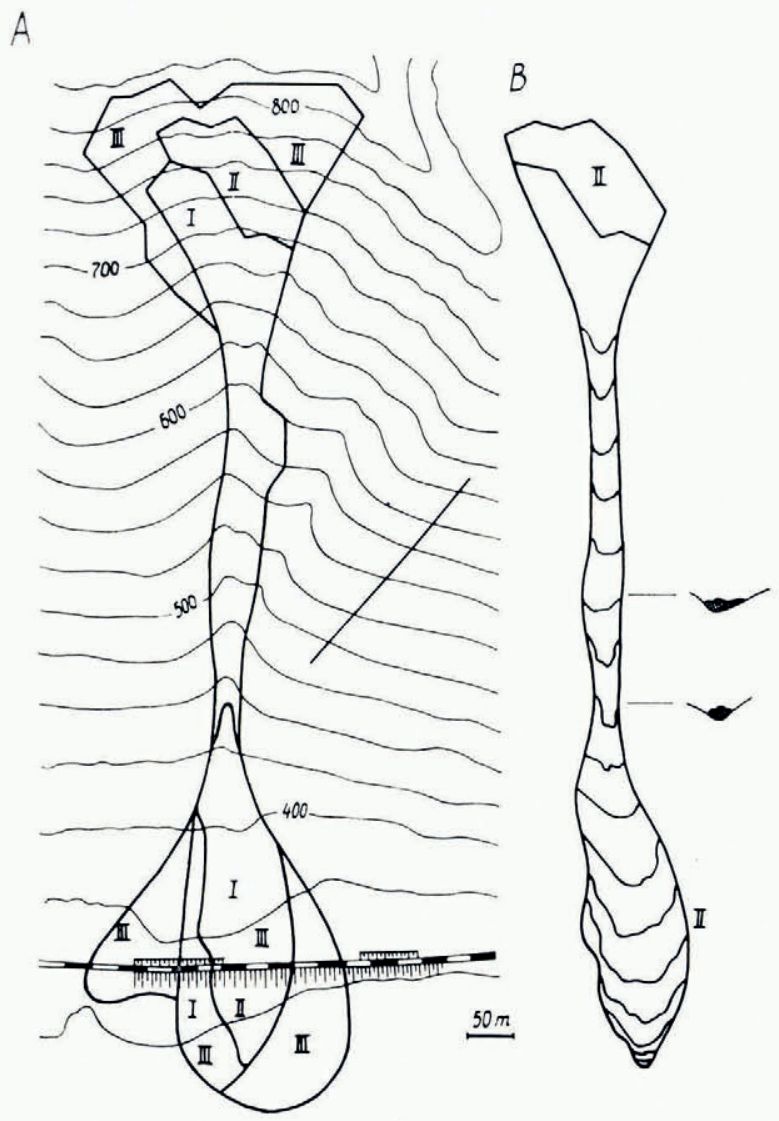

Fig. 4. A. Diagram of the avalanche source the " 5 December Crater" with contours of measured avalanches; B. Avalanche II with positions of its front every two seconds. 
Replacing $p$ by the corresponding expression from Equation (2), we obtain a formula for calculating the maximum avalanche loading "at a point":

$$
p_{\max }=4.8 \gamma_{\mathrm{I}} v^{2} / g \text {. }
$$

The greatest pressure of rock fragments carried by the avalanche snow and hitting the sensors, amounts to about $\mathrm{I} 000 \mathrm{kN} / \mathrm{m}^{2}$, which is a bit less than the pressure of "pure" snow.

The velocity of the avalanche front is an important parameter determining the value of the avalanche pressure. As well as at the "Apatite Crater", it was studied in the similar avalanche "source", the 5 December crater, where in 1974 it became possible to shoot stereoscopic film of three big avalanches triggered by the mine fire (Fig. 4).

The graphical interpretation of stereo-photogrammetric surveys of moving avalanches presented in Figure 5, allows us to conclude at least the following: The velocities of the Khibin avalanches can reach very big values, up to $40-50 \mathrm{~m} / \mathrm{s}$. Secondly, it follows from Figure 5, that a peculiar feature of the studied avalanches is the abrupt decrease in their velocity at the end of a transit channel, followed by its growth at the beginning of the avalanche cone. This phenomenon, called a "velocity depression" turned out to be typical of all the

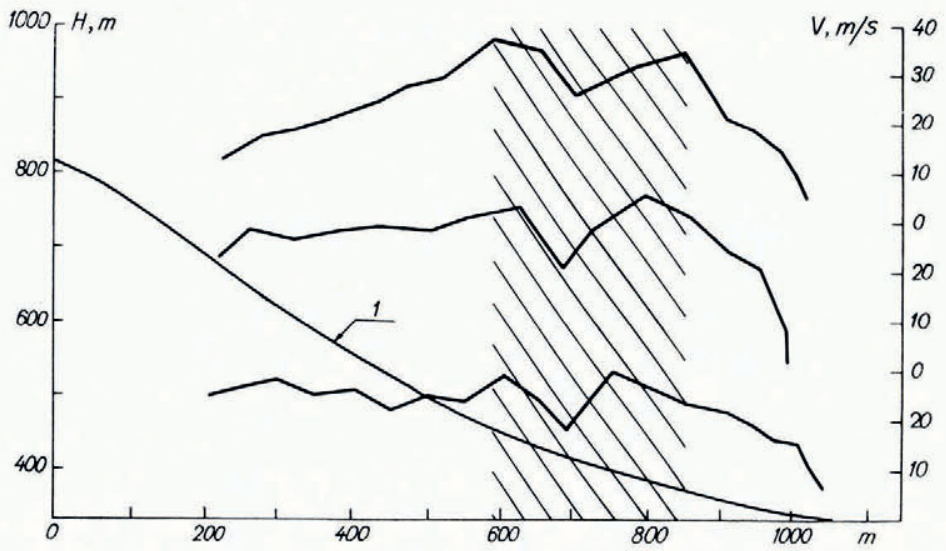

$(A)$

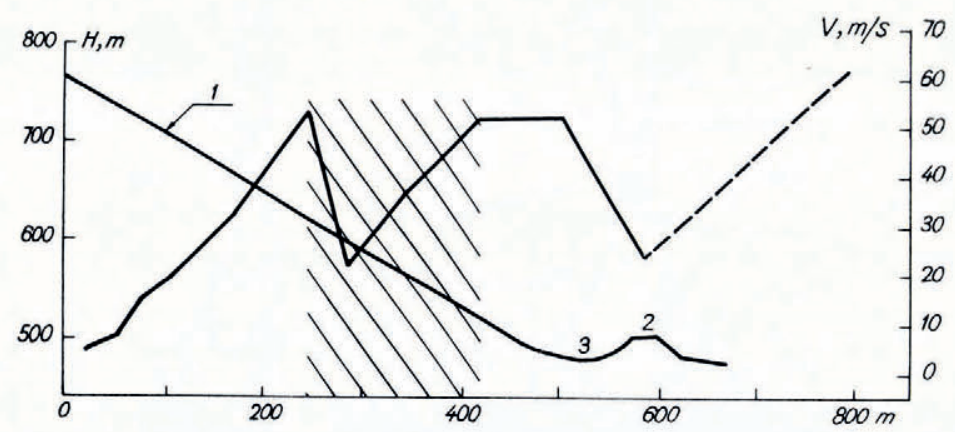

(B)

Fig. 5. Results of measuring the velocities of avalanches by the stereo-photogrammetric method.

A. The avalanche source the " 5 December Crater", 1974 . The longitudinal profile $(I)$ and velocity of three avalanches; the area of "velocity depression" is hatched.

B. The avalanche source the "Apatite Crater", 1975. I: The longitudinal profile of the route of avalanching. 2: Antiavalanche dam. 3: Location of the impact installation. The area of "velocity depression" is hatched. The velocity of the front of the air wave (snow-powder stream) is shown by a dotted line. 
avalanches studied by stereo-photogrammetric surveys. The length of the areas, in which the "velocity depression" was observed, is from $150-200 \mathrm{~m}$, and the velocity falls by a factor of $1.5^{-2.0}$. The greater part of the avalanche snow moves along the underlying surface and consists of snow blocks with the specific weight of $2.0-3.7 \mathrm{kN} / \mathrm{m}^{2}$. Powder-snow portions of an aerosol type are common to every avalanche and are considerable.

The "velocity depression" effect, if its existence is confirmed, will be of evident interest for the choice of the optimum location of avalanche dampers, as suggested by some researchers (Voytkovskiy and others, 1974).

The series of studies of dynamic properties of the Khibin avalanches, fulfilled recently, has drawn our attention to another phenomenon bringing about unwanted effects. We mean

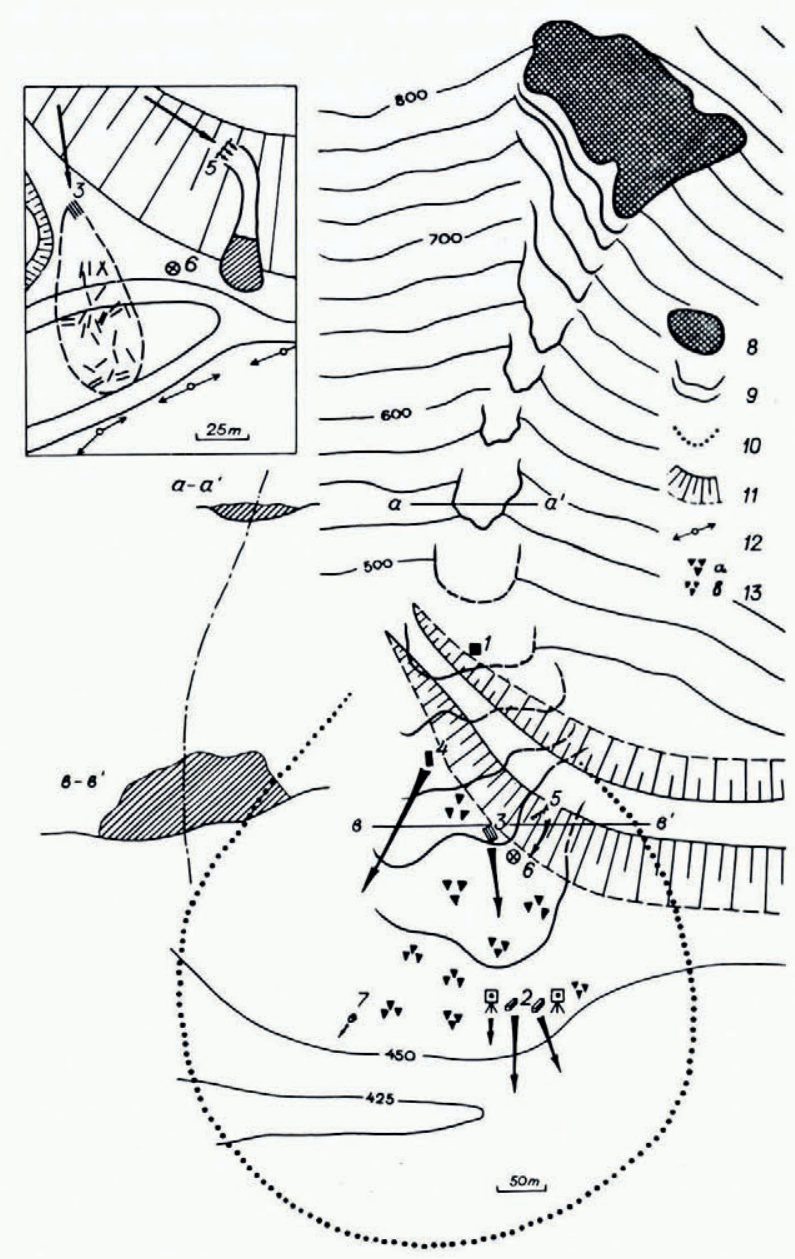

Fig. 6. Sketch map showing the results of filming the activity of avalanche and the air wave in the "Apatite Crater".

I: Impact installation. 2: Location of cameras and directions of their scattering. $3: A$ pile of logs and their position after the scatter. 4: A wooden post and the route of its transportation by the air wave. 6: A traffic sign distorted by the air wave. 7: Location and scatter of empty mine cases. 8: Initial area of moving snow. 9: Position of the front of the avalanche and snow-powder flow (after forcing the dam) every $2 \mathrm{~s}$. 10: The limit of visible traces of the air wave on the surface of the snow cover. 11: Anti-avalanche dam. 12: Electric transmission line. 13: The main sediments of rocks, evacuated by the air wave: $a->I \mathrm{~kg}, b-<_{I} \mathrm{~kg}$. $a-a^{\prime}:$ Cross-section of the avalanche before its collision with the dam. $b-b$ ': Cross-section of the avalanche at the moment of its "jump" from the dam. 
the destructive air waves occurring when an avalanche collides with an anti-avalanche construction of a filling dam type.

Observations have shown that anti-avalanche dams with a height greater than $25 \mathrm{~m}$ cannot stop a dry avalanche moving rapidly. If the avalanche velocity reaches $30 \mathrm{~m} / \mathrm{s}$, the greater part of the avalanche, including the powder-snow portion, attacks the obstacle, trapping an air cavity on its distal side. The release of this compressed air has an explosive nature and is followed by intense and total sputtering of the avalanche snow and by the growing velocity of the front of a snow-powder turbulent jet.

These properties of air waves were most obvious during the disasterous avalanching of I $93^{8}$ (the "Vortkewaiskaya Crater") and of 1975 (the "Apatite Crater"). A set of stereophotogrammetric equipment was installed on the latter avalanche cone and thus, it was thoroughly studied (Fig. 6). Among the most interesting peculiarities of the air wave observed in 1975 we should enumerate the following: (I) the radial nature of traces of the wave on the snow mantle and of the scatter of fragments of damaged objects; (2) the occurrence of a small avalanche induced by the effect of an air wave on the snow mantle on the distal side of the dam; (3) the scatter of fragments of rocks weighing as much as $\mathrm{I} k \mathrm{~kg}$ to a distance of $300 \mathrm{~m}$ from the place of their primary location on the dam.

The nature of avalanche-born air waves still remains obscure in many of its aspects and is treated differently by different researchers. The theoretical foundation of anti-air-wave protection has not yet been developed, though it is needed badly.

Practice shows that negative forms of topography serve as the most reliable protection from avalanche air waves and avalanches themselves. Slope-abutting quarries occurring in course of mining in the Khibins may serve as an example. These peculiar "avalanche traps" with a depth of $100-200 \mathrm{~m}$, have volumes of up to $5^{-10} \times 10^{6} \mathrm{~m}^{3}$ and can kill the energy of any avalanche. The damping of the energy of a flowing avalanche corresponds to the known principle of the "hydraulic jump"; air waves occurring are neutralized by the walls of the quarry. Due to the method applied, it became possible to reduce the duration of the avalanche and air waves by $300-500 \mathrm{~m}$.

The dimensions of these quarries by far exceed the dimensions of the avalanches, and now the problem is to develop by scientific calculation methods of designing similat constructions specially for protection against avalanching. Such protective constructions should be economically expedient and technically feasible.

\section{REFERENCES}

Dolov, M. A., and Khalkechev, V. A. 1972. Fizika snega i dinamika snezhnykh lavin [The physics of snow and dynamics of snow avalanches]. Vysokogornyy Geofizicheskiy Institut. Trudy, Vyp. 23.

Goff, A. G., and Otten, G. F. 1939. Eksperimental'noye opredeleniye sily udara snezhnikh obvalov [Experimental determination of the impact of snow avalanche]. Izvestiya Akademii Nauk SSSR. Seriva Geograficheskaya, 1939. No. 23.

Goff, A. G., and Otten, G. F. 194I. Diagramma davleniya pri udare snezhnogo obvala [Pressure diagram of the impact of a snow avalanche]. Izvestiya Akademii Nauk SSSR. Seriya Geograficheskaya, I 941, No. 3.

Isayenko, E. P. 1972. Proyektirovaniye zheleznykh dorog v lavinoopasnykh rayonakh. Metodicheskiye ukazaniya [On the designing of railways in avalanche-prone regions. Recommendations]. Novosibirsk, Novosibirskiy Institut Ingenerov Zheleznodorozhnogo Transporta.

Rzhevskiy, B. N., and Nechayev, N. F. 1975. K metodike izmereniya udarnoy sily lavin mekhanicheskimi datchikami [On the methods of determinating an avalanche impact by means of sensors]. (In Rzhevskiy, B. N., ed. Issledovaniya snega i lavin $v$ Khibinakh. Leningrad, Gidrometeoizdat, p. 40-50.)

Samoylov, V. A., and Bryukhanov, A. V. 1975. K usovershenstvovaniyu metodiki stereofotogrammetricheskogo izucheniya dvizheniya snezhnikh lavin [On the development of methods of stereophotogrammetric surveys of the motion of snow avalanches]. (In Rzhevskiy, B. N., ed. Issledovaniya snega $i$ lavin $v$ Khibinakh. Leningrad, Gidrometeoizdat, p. $18-23$.)

Shimizu, H., and others. 1974. Kurobe-kyōkoku kōsoku-nadare no kenkyū. III [Study of high-speed avalanche in Kurobe canyon. III]. [By] H. Shimizu [and 5 others]. Teion-kagaku: Low Temperature Science, Ser. A, [No.] 32 , p. $113^{-27}$. 
Shōda, M. 1966. An experimental study on dynamics of avalanches snow. Union de Géodésie et Géophysique Internationale. Association Internationale d'Hydrologie Scientifique. Commission pour la Neige et la Glace. Division Neige Saisonnière et Avalanches. Symposium international sur les aspects scientifiques des avalanches de neige, 5-10 avril 1965 , Davos, Suisse, p. $215^{-29 d . ~(P u b l i c a t i o n ~ N o . ~ 69 ~ d e ~ l ' A s s o c i a t i o n ~ I n t e r n a t i o n a l e ~ d ' H y d r o l o g i e ~ S c i e n t i f i q u e .) ~}$

Spindler, A. 1957. Aktiver Lawinendruck und dessen rechnerische Prüfung durch Messungen. Schweizerische Bauzeitung, Jahrg. 75 , Ht. 42, p. 675-78.

Sredneasiatskiy Nauchno-Issledovatel'skiy Gidrometeorologicheskiy Institut. 1965. Rukovodstvo po snegolavinnym rabotam [A guide on snow avalanche works]. Leningrad, Gidrometeoizdat.

Vitman, F. F., and Yoffe, B. S. 1948. Prostoy metod nakhozhdeniya dinamicheskoy tverdosty metallov s pomoshchyu dvustoronnego konusa [A simple method of determination of dynamic hardness of metals with the help of a two-sided cone]. Zavodskaya Laboratoriya, 1948, No. 6, p. 727-32.

Voytkovskiy, K. F., and others. 1974. Podvesnoy sborniy lavinogasitel' [Suspended sectional avalanche damper]. [By] K. F. Voytkovskiy, A. M. El'mesov, I. I. Kherkhleulidze. (In Dolov, M. A., ed. Fizika snega i dinamika snezhnykh lavin [The physics of snow and dynamics of snow avalanches]. Vysokogo nyy Geofizicheskiy Institut Trudy, Vyp. 26, p. $15^{8-65}$.)

\section{DISCUSSION}

B. SALM: You did say that when an avalanche flows faster than $30 \mathrm{~m} / \mathrm{s}$ the defence of objects by a dam (perpendicular to the direction of movement) becomes impossible? I think one has to design a dam by the velocity head $\left(v^{2} / 2 g\right)$, and then decide whether it is feasible or not.

V. M. Kotryakov: I agree and I would like to add that the defence of objects depends on the height of the dam $(20-25 \mathrm{~m}$ in the Khibins) but increasing the height of the dam is out of the question, not only because of the expense but also because of avalanche formation on the slopes of the dam itself.

T. LANG: Do you keep the area in front of the dam clear of snow accumulation prior to the avalanche flow?

KotLyakov: Deposits from any previous avalanche in front of the dam are cleared, but some remnants may remain till the next avalanche. 